\title{
O MEDO, 0 LOCUS HORRIBILIS E O MONSTRUOSO NO CONTO “A PESTE”, DE JOÃO DO RIO
}

Eduardo da Rocha Marcos Patricia Hradec

Recebido em 06 dez 2020. Eduardo da Rocha Marcos é doutor e pesquisador Aprovado em 25 jan 2021. do grupo de pesquisa de Literatura no Contexto Pós-Moderno.

http://lattes.cnpq.br/5849517795301589

https://orcid.org/0000-0002-0432-3005

ed_marcos@terra.com.br

Patricia Hradec é doutora e pesquisadora do grupo de pesquisa Estudos do Gótico.

http://lattes.cnpq.br/4021161559558051

https://orcid.org/0000-0001-5171-9566

patriciahradec@gmail.com

Resumo: Em pleno século XXI, a humanidade é assolada por um vírus que, em poucos meses, se espalha. Famílias inteiras são dizimadas nessa pandemia, fazendo com que as pessoas repensem sua forma de viver. A literatura, por vezes, retrata a realidade, mas também a subverte e até a adverte para os problemas do cotidiano. Assim, o conto "A peste", de João do Rio, dialoga com a nossa época, pois retrata a angústia e o desespero de um Rio de Janeiro, no início do século $X X$, enfrentando a peste da varíola. A narrativa apresenta os três elementos 
ligados ao Gótico: o medo, o locus horribilis e o monstruoso. Analisaremos como cada elemento está exposto no conto e para tanto usaremos teóricos como Fred Botting, David Punter e Glennys Byron para situar o gótico; também o pensamento de Júlio França e Pedro Sasse será utilizado para conceituar o medo, e expor sua trajetória, além de Julia Kristeva para pensarmos no monstruoso, uma vez que a peste transforma as pessoas, aqueles que conseguiram sobreviver a ela, em abjetos. O medo e o locus horribilis acabam se tornando crescentes até culminar no monstruoso, num relato de angústia e desespero, típico da literatura gótica.

Palavras-chave: "A peste". João do Rio. Locus horribilis. Medo. Monstruoso.

Abstract: In the 21st century, humanity is plagued by a virus that, in a few months, spreads. Entire families are wiped out in this pandemic, causing people to rethink their way of living. Literature sometimes portrays reality, but it also subverts it and even warns it of everyday problems. Thus, the short story "A peste", by João do Rio, dialogues with our time, as it portrays the anguish and despair of a Rio de Janeiro, at the beginning of the 20th century, facing the smallpox plague. The narrative presents the three elements linked to Gothic: the fear, the locus horribilis and the monstrous. We will analyze how each element is exposed in the short story and for that purpose we will use theoreticians such as Fred Botting, David Punter and Glennys Byron to situate the Gothic; the thought of Júlio França and Pedro Sasse will be also used to conceptualize the fear and expose its trajectory, in addition to Julia Kristeva to think of the monstrous, since the plague turns people, those who managed to survive it, into abjects. The fear and the locus horribilis end up growing until culminating in the monstrous, in an account of anguish and despair, typical of Gothic literature.

Keywords: "A peste". Fear. João do Rio. Locus horribilis. Monstrous. 


\section{INTRODUÇÃO}

O mundo jamais seria o mesmo quando, ao final de 2019, cientistas chineses anunciaram a descoberta de um novo vírus, que se alastrou por todos os continentes e assolou a população mundial. O impacto do novo coronavírus foi tão devastador que chegou a ser considerado como o maior desafio desde a Segunda Guerra Mundial, segundo pronunciamento da chanceler alemã, Angela Merkel, em março de 2020.

O episódio, de proporções globais, revelou faces de um mundo marcado por características individualistas, questionamentos à ciência, ao desenvolvimento, às relações sociais e ao modo de interação na sociedade dita pós-industrial.

$\mathrm{Na}$ literatura, muitas dessas nuances já eram antecipadas havia pelo menos um século pelo escritor e jornalista João do Rio, personagem de destaque no cenário carioca do início do século passado. Em sua escrita estão demarcados aspectos como o pânico e o medo causados pelas epidemias da época, a incredulidade diante do real, a desestabilização da sociedade diante de um mal que subitamente se apossa dela, e os transtornos causados pelo advento da modernidade e da vida urbana.

O caráter iconoclasta, a propósito, foi uma das marcas de João do Rio, e está presente em sua coletânea de contos Dentro da Noite, considerada por seu biógrafo João Carlos Rodrigues como "a maior coleção de taras e esquisitices até então publicada na literatura brasileira" (2010, p. 135).

Rodrigues aponta também os referenciais que serviram de diálogo para a obra de João do Rio: 
Mais do que pela obra de Wilde, de quem João do Rio foi admirador e tradutor, Dentro da Noite é muito influenciado por dois outros autores, hoje fora da moda. Um é o médico austríaco KrafftEbing, cujo Psycopathia sexualis (1886) era o que de mais avançado havia sobre anomalias sexuais antes da aparição das obras de Freud. O outro é Jean Lorrain (Paul Duval), o mais decadente dos decadentistas franceses. (2002, p. 12)

Repleto de críticas ao conservadorismo sexual da época, ao contraste no convívio entre a elite e as classes menos abastadas, o livro contém pelo menos três contos dedicados ao medo provocado pelas doenças contagiosas, como "O bebê de tarlatana rosa", "A peste" e "O carro da Semana Santa". Desses, escolhemos "A peste" como objeto de análise para retratar algumas das características de João do Rio, e por se tratar de um conto discursivamente inserido em nosso contexto de pandemia.

Em nossa análise, destacamos alguns pontos que o inserem no âmbito da literatura gótica, como a construção do medo, o espaço aterrorizante e a manifestação do monstruoso.

O objetivo deste trabalho é demarcar os elementos que elevam o texto de João do Rio ao patamar do goticismo, bem como entender como os recursos da literatura Gótica se articulam intrinsecamente ao longo da narrativa, apontando para caminhos cognitivos tão atuais quando refigurados (no sentido ricoeuriano) pelo leitor.

Para tanto, faremos uso das concepções teóricas dos conceitos concebidos pelos estudiosos do gótico David Punter, Glennys Byron e Fred Botting, o pensamento sobre o medo, dos pesquisadores Júlio França e Pedro Sasse, e a concepção de monstruoso, da estudiosa Julia Kristeva. 


\section{"A PESTE"}

Publicado inicialmente na edição de 27 de fevereiro de 1910, no periódico Gazeta de Notícias, e posteriormente lançado na coletânea Dentro da Noite, no mesmo ano, "A peste" se insere no contexto social do início do século $X X$, período em que o Brasil se deparou com diversas doenças epidêmicas, como a febre amarela, a peste bubônica e a varíola. O conto, em particular, refere-se aos transtornos sociais causados por esta última, também conhecida como bexiga. A enfermidade, transmitida pelo vírus orthopoxvirus variolae, através do contato com a saliva, se espalha no organismo pela corrente sanguínea e se instala na região da pele, provocando erupções, dores no corpo, febre, mal estar e problemas gástricos. No caso da varíola major, o tipo mais radical da doença, a letalidade era de $30 \%$.

Para se ter uma ideia do acentuado poder de infecção da varíola, somente no ano de 1904 o Hospital São Sebastião, citado no conto, registrou a internação de 1.800 pacientes, lembrando que a população do Rio de Janeiro, segundo o censo do IBGE de 1900 , era de 811.443 habitantes.

A doença também foi protagonista do episódio que entrou para a história como a Revolta da Vacina, em que o médico, cientista e epidemiologista Oswaldo Cruz teve de enfrentar a oposição do senador paraense Lauro Sodré (1858-1944), que liderou no Congresso um movimento contra o projeto de obrigatoriedade da vacinação apresentado a pedido de Cruz.

É este cenário, portanto, caracterizado pela expansão de uma epidemia, pelo questionamento da legislação de saúde pública e das precárias condições de higiene, que João do Rio vai retratar em sua obra. 


\section{O CONTO}

Localizado na cidade do Rio de Janeiro, "A peste" narra a história de dois amigos, Luciano e Francisco. É apresentado ao leitor um cenário assolado pelo inesperado pavor causado pela varíola. Inicialmente, Luciano se mostra descrente da ocorrência da epidemia e tenta mostrar ao amigo que o cotidiano não deve ser alterado. Francisco, ao contrário de Luciano, se revela extremamente preocupado, chegando a se precaver, tomando quinino e antissépticos para afastar o vírus, e lendo os jornais para se manter informado. Francisco decide se isolar no Corcovado para se prevenir da doença. Luciano é informado pouco depois que o amigo fora internado no Hospital São Sebastião. Decide-se por visitá-lo. Durante o caminho, vai tendo conhecimento cada vez mais próximo dos efeitos da varíola na cidade, estampados nas personagens que ele encontra pela rua. Ao chegar ao hospital, defronta-se com um cenário de horror. Enquanto os funcionários procuram pelo amigo, Luciano mergulha num mar de questionamentos sobre a doença e seus efeitos. Um enfermeiro confirma que Francisco está vivo, e afirma que ele irá sobreviver. Luciano decide vê-lo, mas é persuadido pelo diretor a ir para casa. Mesmo assim Luciano insiste. Ao chegar no quarto onde se encontra Francisco, Luciano se depara com o horror, devido às sequelas que a doença estampou no rosto do amigo. Ele deixa o hospital apavorado e certificado de que a varíola realmente existe. No último parágrafo, numa brusca mudança de foco narrativo, o leitor tem o conhecimento de que Luciano também fora contaminado, e que se encontra em isolamento social. 


\section{ANÁLISE}

A partir da leitura do texto, podemos detectar alguns elementos que apontam para a possibilidade de inserir o conto de João do Rio dentro do espectro do goticismo: o medo, revelado minuciosamente, vai sendo articulado desde o início da narrativa com o espaço. Conforme veremos, um alimenta o outro na elaboração espacial criada pelo autor. O local de horror culmina com a manifestação do monstruoso, ao final da narrativa, que possui um sentido singular dentro do projeto literário de João do Rio. No conto, o autor faz uso de elementos do gótico como pretexto para tratar da problemática urbana, abordando minuciosamente os desvios comportamentais e as contradições humanas.

O conto se inicia com a escrita em in última res e o narrador em primeira pessoa, Luciano Torres, descrevendo o cenário no momento em que está sendo levado para o isolamento social, após descobrir que está com a bexiga.

E de súbito, um indizível pavor prega-me ao banco. É um dia brumosamente invernal. O azul do céu parece tecido de filamentos de brumas. 0 sol como que desabrocha, entre as brumas. $\mathrm{O}$ ar, um pouco úmido e um pouco cortante, congela as mãos, tonifica a vegetação, e o mar, que se vê à distância num recanto de lodo, tem reflexos espelhentos de grandes escaras de chagas, de óleo escorrido de feridas, à superfície quase imóvel. O cheiro de desinfecção e ácido fênico, o movimento sinistro das carrocinhas e dos automóveis galopando e correndo pela rua de mau piso [...] a sinistra galeria de caras de choro que os meus olhos vão vendo, põe-me no peito 
um apressado bater de coração e na garganta como um laço de medo. (RIO, 2002, p. 148)

Na primeira frase, o medo traduz a tônica que conduz o conto, pois subitamente ele se instala no íntimo da personagem, pregado ao banco, sob o léxico do pavor. $\mathrm{O}$ ambiente, elemento fundamental na caracterização da literatura gótica, logo no primeiro parágrafo, é retratado como um dia brumoso e congelante.

O que o narrador nos oferece, neste início, é a construção de um texto com elementos góticos bastante distantes da abordagem comum às narrativas do final do século XVIII, mas que se aproxima da escrita do século XIX, em que prevalece o espaço como componente aterrorizante, como nos atesta David Punter e Glennys Byron:

Se existe uma topografia geral do Gótico, então o motivo é o castelo. Costuma-se dizer que o gênero tem origem, por exemplo, com O Castelo de Otranto, de Horace Walpole (qq.v.), um local de espectros e milagres, cuja 'parte inferior... foi escavado em vários claustros intrincados', e, portanto, contém um "longo labirinto de escuridão", e cuja parte superior fornece uma cena, embora frequentemente atormentada, de magnificência feudal. (2004, p. 259, tradução nossa)

Este local onde se desenvolve a narrativa gótica, no entanto, passa por uma série de transformações no decorrer do tempo, chegando a atingir, ao longo do século XIX, uma série de transmutações. O castelo assombrado, a masmorra, a catedral gótica e o ambiente sombrio convertem-se na casa soturna, no ambiente doméstico e urbano que se caracterizam como "os loci para mistério e terror" (BOTTING, 1996, p. 80, tradução nossa), compondo uma evidência da transformação 
dos tempos. "A aparente realidade dos horrores da cidade evoca emoções que fazem perguntas à ordem social, emoções relacionadas com medos no presente imediato, em vez de deslocadas para um passado distante" (BOTTING, 1996, p. 82, tradução nossa).

A narrativa gótica sofre um deslocamento do ambiente campestre para uma nova atmosfera, agora inserida no universo urbano, onde se desenvolverá uma nova escrita soturna, acompanhando a evolução da sociedade capitalista. O medo deixa o passado para ser o presente, conforme podemos observar nesse conto com a cidade infestada por uma doença.

Concomitantemente, o medo também levará esta nova poética gótica a sofrer profundas transformações. De acordo com Júlio França e Pedro Sasse, o elemento sobrenatural, na figura do monstro, passará a ser desenvolvido nesse novo locus.

Se, nas narrativas do horror sobrenatural, os monstros, os ambientes e os objetos insólitos são responsáveis por criar o medo como efeito de recepção, nas narrativas do medo natural, as causas dessa emoção estão em aspectos cotidianos da vida. Na literatura de medo sobrenatural, o horror é materializado, corporificado na figura do monstro, personagem arquetípico desse tipo de literatura. No medo urbano, porém, ele se encontra disperso no espaço, no caos da vida metropolitana moderna. (2012, p. 33-34)

Portanto, é nesse novo espaço, que se transforma ao longo do século XIX e adentra o século XX, que a narrativa gótica propiciará condições para que a ação transcorra, trazendo junto a si uma série de particularidades na construção do medo e seu efeito catártico no leitor. 
No conto "A peste" este procedimento é adotado logo no início, conforme a construção demonstrada no primeiro parágrafo. O medo urbano e o locus se alimentam mutuamente, e assim vão se constituindo ao longo da narrativa. À descrição do clima de inverno, vão sendo acrescentadas características semânticas que conferem à paisagem indícios de uma cidade tomada pela contundência da doença, conforme observamos nas "grandes escaras de chagas" e em "óleo escorrido de feridas". "O cheiro de desinfecção e ácido fênico" imergem sinestesicamente o leitor no ambiente epidemiológico. Para completar a cena, caras de choro apressam o bater do coração, instalando o medo no narrador-personagem.

Luciano descreve a situação aterradora em que se encontra, a partir da notícia do contágio de um amigo, que já está no isolamento. "A bexiga! A bexiga! É verdade que há uma epidemia... E eu vou para lá, eu vou para o isolamento, eu!" (RIO, 2002, p. 148).

Na sequência, num movimento anacrônico, o narrador faz uso de uma analepse para recuar no tempo e revelar como toda aquela situação tivera início, com o descaso pela epidemia: "Um mês antes ria dessa epidemia. Para que pensar em males cruéis, nesses males que deformam o físico, roem para todo o sempre ou afogam a vida em sangue podre? Para que pensar?" (RIO, 2002, p. 149).

O narrador revela desprezo diante da epidemia, rindo da situação e se colocando numa posição cética diante do terrível contexto. Em contraposição, seu amigo Francisco se dividia entre a realidade narrada pelos jornais e as estatísticas da ocasião: " $\mathrm{A}$ média de casos fatais é de trinta por dia. Ela vem aí, a vermelha" 
(RIO, 2002, p. 149). A voz antagônica de Francisco exerce o papel de espelho invertido de Luciano, e é delineada pelo tom de advertência ao amigo.

No entanto, a fala baseada no apreensivo cotidiano factual relatado pelos jornais é acompanhada de hábitos baseados no senso comum: "já organizara um regime, tomara quinino, tinha o quarto cheio de anti-sépticos [sic], os bolsos com pedras das farmácias para afastar o vírus" (RIO, 2002, p. 149).

Luciano e Francisco se apegavam aos hábitos que praticavam, como forma de manter a rotina, negar a doença, e buscar um local seguro: "Andamos todo o dia pelas ruas, vamos aos teatros. Qual varíola! Vê como toda gente ri e goza. Deixa de preocupações" (RIO, 2002, p. 149). O espaço artístico como refúgio da cruel realidade remete-nos a um diálogo com a obra do escritor francês Jean Lorrain, representante da Belle Époque parisiense, de quem João do Rio era leitor. Fábio Lucas Pierini, estudioso da narrativa de Lorrain, descreve-nos a forma como essa fuga da realidade se manifesta nos contos do autor francês: "seus personagens refugiam-se no mundo da arte, onde tudo tem uma lógica e um objetivo, um enigma propositalmente criado para ser decifrado e dar sentido à vida do investigador" (2019, p. 8-9).

Essa lógica, em João do Rio, pode ser interpretada como um escapismo do mundo real rumo à ficção, onde a realidade não fere e o espírito é regenerado pela trivialidade dos atos banais. Atua como busca por um lugar seguro, onde não existem ameaças. Em outras palavras, trata-se de uma espécie de transmutação do locus amoenus, que segundo o E-Dicionário de Termos Literários de 
Carlos Ceia, representa a "paisagem ideal" (ALVES, 2009, s.p.) e tem origem na Antiguidade Clássica como uma "descrição da Natureza e para um conjunto de elementos específicos: o campo fresco e verdejante, com um vasto arvoredo e flores coloridas, cujo doce odor se espalha com a brisa" (ALVES, 2009, s.p.).

Já na literatura cristã, este mesmo local é exposto no Gênesis como "um local perfeito onde, através da ação de Deus, podemos encontrar uma enorme variedade de árvores de frutos saborosos e um rio que corre ao sabor da brisa amena" (ALVES, 2009, s.p.). Na literatura do século XVII, ele se apresenta como uma oposição ao conceito do locus horribilis. Desta forma, se podemos constatar uma transmutação do local de horror, que parte do castelo assombrado no séc. XVIII, avança sobre as casas soturnas no XIX e conquista o espaço urbano no século $X X$, o mesmo raciocínio podemos aplicar para esse local de amenidades, que parte do histórico ambiente bucólico e alcança o espaço urbano, representado pelo mundo das artes.

Diálogos entre Lorrain e João do Rio aparecem em outros contos de Dentro da Noite, como em "Os furos da máscara" (1895), de Lorrain, e "O bebê de tarlatana rosa" (1908). Na obra do francês, uma dupla de amigos decide ir a um baile de carnaval, em que os participantes estão todos mascarados. Na escrita de João do Rio, o protagonista se envolve e se deixa seduzir por uma pessoa fantasiada e mascarada também num baile de carnaval. Os pontos de contato ocorrem também entre "Os furos da máscara" e "O carro da Semana Santa" (data não localizada), onde o espaço sagrado é profanado no decorrer da ação. No primeiro, a história se passa numa "igreja abandonada e desativada" (LORRAIN, 2019, 
p. 93), enquanto que na segunda narrativa, o ato de sedução ocorre numa procissão: "A dolorosa cerimônia tinha qualquer coisa de orgíaco, como em geral as cerimônias religiosas deste fim de raça, em que os instintos inconfessáveis se escancaram no atrito dos corpos, nos grandes agrupamentos." (RIO, 2002, p. 191).

Retomando a questão do medo em "A peste", ele continua presente na composição narrativa de João do Rio. Espalha-se pelos cantos e esquinas do ambiente urbano, como se fosse a própria doença:

A sinistra rebentava em purulências toda a cidade. Um dia em que passava por uma igreja, Francisco ouviu os sinos a badalar sinistramente. Teve a curiosidade de saber por quem tão tristes badalavam e perguntou a um velho. - É promessa, meu senhor, é para que Santo António não mate a todos nós de bexiga. (RIO, 2002, p. 149)

Mais uma vez, o aspecto sensorial constrói o ambiente de terror. Assim como a doença, o medo alheio, no cenário urbano, é infectante, como podemos constatar na passagem seguinte:

Há uma semana, indo por uma rua de subúrbio, encontrou com gritos e imprecações um bando de gente que arrastava ao sol um caixão. Era uma pobre família levando à igreja o cadáver de uma criança em holocausto, para que Deus tivesse piedade e misericórdia. A impressão prostrou-o. Chegou à casa ainda mais assustado. (RIO, 2002, p. 149-150)

O medo, como uma doença, se alastra pelo espaço urbano. Ele está no dia "brumosamente invernal", no mar "espelhento de grandes escaras de chagas", na igreja e se faz presente no badalar de 
um sino, nas ruas, no cortejo de uma criança, enfim o medo está por todos os lados, e por possuir a propriedade da onipresença, ele se potencializa no espaço urbano. Como nos relembra França e Sasse, "o habitante da cidade está exposto a um somatório de pequenos medos, que acabam por fim fundindo-se em uma única, ainda que dispersa, ameaça: o próprio ambiente urbano" (2012, p. 34).

No conto "A peste", assim como em vários outros de Dentro da Noite, além de o medo estar pulverizado pela cidade ele também vai crescendo no interior do narrador de uma maneira gradativa. Primeiro veio o descrédito diante do mal. Depois, ele começa a ser notado. E após ser notado, vai aumentando a percepção de que ele existe: "Estamos perdidos. A polícia já deixa arrastarem os variolosos pela rua. Dentro em pouco só lepra, a lepra de dentro encherá as ruas. Cada dia aumenta mais, cada dia aumenta" (RIO, 2002, p. 150, grifo nosso).

Pela primeira vez, o narrador assume a possibilidade de ser alvo da peste: "Quando chegará a nossa vez?" (RIO, 2002, p. 150). O que era motivo de chacota ganha ares de realidade, e agora traz consigo a possibilidade efetiva da morte. $\mathrm{O}$ assombro com a finitude causa curiosidade no narrador-personagem. Luciano, pela primeira vez manifesta interesse em saber mais sobre a doença. "E comecei eu também a indagar, a querer saber. [...] Como se morria de bexigas?" (RIO, 2002, p. 150).

Luciano fica sabendo que Francisco se retirara para o Corcovado. Passa a ter conhecimento, a partir de uma nota de jornal, que o amigo fora internado, o que lhe causa mais medo e incertezas: "[...] sabia por uma nota que ele estava no São Sebastião, com bexiga também, talvez morto!" (RIO, 2002, p. 150). 
Inicialmente, julga Francisco um covarde. Ao mesmo tempo, hesita em visitá-lo, com medo do contágio e da morte. Pondera. E decide não abandonar o amigo naquela situação. "[...] Era preciso vê-lo, não era possível deixá-lo morrer sem um amigo ao lado" (RIO, 2002, p. 150).

Diante dessa situação, vem novamente a não aceitação da gravidade da doença: "Nunca tive medo de moléstias, morre quem tem de morrer. Depois a cidade estava tão alegre, tão movimentada, tão descuidosa" (RIO, 2002, p. 150).

A tranquilidade de Luciano é passageira. A morte e o horror fazem questão de se fazer presente em seu caminho. "Tomei o tramway quase tranquilo. Mas ali, tudo indica a morte, a angústia, o horror, ali é impossível e eu sentia um frio, um frio..." (RIO, 2002, p. 150).

Ao chegar ao hospital, um novo encontro com a morte:

Aquele recanto, aquele hospital com ar de cottage inglês aviltado por usinas de porcelana, é bem o grande forno da peste sangrenta. Como deve morrer gente ali, como devem estar morrendo naquele instante. Desço a rua atordoado, com um zumbido nos ouvidos. O mar é um vasto coalho de putrefações, de lodo que se bronzeia e se esverdinha em gosmas reluzentes na praia morna. O chão está todo sujo, e passam carroças da Assistência, carroças que vêm de lá, que para lá vão. Quase não há rumor. É como se os transeuntes trouxessem rama de algodão nos pés. Só as carroças fazem barulho. E quando param - como elas param! - é o pavor de ver descer um monstro varioloso, desfeito em pus, seguindo para a cova. (RIO, 2002, p. 150-151) 
O hospital, o mar e a rua são espelhos de horror. Luciano parece cercado e oprimido pela atmosfera monstruosa. "Tudo é branco, limpo, asseado, com o ar indiferente nas paredes, nos móveis sem uma poeira. Os empregados, porém, movem-se com a precipitação triste a que a morte obriga os que ficam" (RIO, 2002, p. 151).

A incerteza sobre as notícias do amigo causa-lhe desconfortos físicos e pela primeira vez admite: "Eu tenho medo, oh! Muito medo" (RIO, 2002, p. 151).

A seguir, a desumanização dos enfermeiros acentua o clima de angústia. Pacientes são tratados como números num contexto de banalização da morte e num certo esvaziamento do sujeito. "-Olhe, 425? Morreu ontem à noite. Se já seguiu? Já." (RIO, 2002, p. 151). Luciano se revela atordoado, e o fluxo de consciência demonstra o teor de suas divagações:

Quantas mães sem filhos! Quantos pais à espera da certeza da morte dos filhos! Quantos filhos ali, apenas para tratar do enterro dos que lhe deram o ser. Ela não respeita idade, passa a foice purulenta em tudo, está reinando, fora, no jardim, entre as árvores, morro acima. (RIO, 2002, p. 152)

O terror que assola a cidade mostra sua face democrática e implacável, pois é capaz de matar pais, mães e filhos, dilacerando famílias e ocupando todos os espaços urbanos, desde os jardins até o morro acima, onde habitam os mais pobres.

Na sequência, a frieza da burocracia administrativa cadencia a rotina de infelicidade. Os parentes, sentados, esperam alguma notícia fatídica. Há os que se salvarão da morte, mas não serão poupados das marcas do horror. 
Os retintins telefônicos continuam. Algumas faces não dizem nada. Estão lá sentadas, esperando, esperando, esperando. E há marcados, marcados do terrível mal, que vão sair, não morreram, estarão dentro em pouco na rua com a fisionomia torcida, roída, desfeita para todo o sempre. (RIO, 2002, p. 152)

O autor tece na narrativa as condições necessárias para a criação do clímax, que se dará a partir da figura do monstruoso. Se para França e Sasse (2012), nas narrativas do medo urbano o monstro perdeu sua singularidade e passou a ser onipresente, confundindo-se com o próprio espaço, o mesmo não podemos afirmar em relação ao monstruoso, que será o responsável por apontar para aquilo que é temido na sociedade, como no conto em questão, em que é materializado na figura do humano.

Esses seres monstruosos "problematizam o pensamento binário e exigem um repensar dos limites e conceitos de normalidade" (PUNTER; BYRON, 2004, p. 264, tradução nossa). De certa forma, eles subverteram a morte e estão expostos "para definir e construir a política do 'normal'. Localizados nas margens da cultura, eles policiam os limites do humano, apontando para aquelas linhas que não devem ser cruzadas" (PUNTER; BYRON, 2004, p. 263, tradução nossa).

E, adjacente ao prenúncio desse monstruoso, se manifesta mais uma vez o medo, nas indagações de Luciano: "E Francisco? Ficará assim? Assim, horrível, horrível... É preciso vê-lo! É preciso!" (RIO, 2002, p. 152).

O medo surge, agora, numa nova configuração, a da fria estatística, narrada pelo diretor: "Tenho presentemente no hospital 
setecentos e vinte doentes, desde varíola hemorrágica, que mata em horas, até a bexiga branca, que nem sempre mata. Já não há lugares. Nunca São Sebastião esteve assim" (RIO, 2002, p. 152).

Luciano pergunta por Francisco, e o diretor pede para um funcionário ir procurá-lo. Desta vez, a espera toma conta da mente do narrador, mergulhando-o num mar de indagações aflitivas: "O funcionário saiu, e desde que saiu, um tremor apoderou-se do meu corpo. Estaria morto? Estaria vivo?" (RIO, 2002, p. 153).

Luciano tenta quebrar o clima de nervosismo aludindo assuntos triviais. "A epidemia tem impedido vários prazeres da season. As grandes estrelas mundiais, os teatros." (RIO, 2002, p. 153). Neste ponto, o narrador busca resgatar, mais uma vez, o locus amoenus, como forma de amenizar o seu descontrole emocional. No entanto, a conversa direcionada para as trivialidades não encontra eco no interlocutor, que afirma não ter tempo para tal diversão. E ainda completa banalizando a morte dentro ambiente urbano: "- Nas grandes cidades as pestes dão uma impressão muito menos dolorosa do que outrora" (RIO, 2002, p. 153).

Ao descobrir que o amigo Francisco está vivo, Luciano manifesta o desejo de querer vê-lo. O diretor tenta dissuadi-lo, mas ele insiste. O caminho até o leito onde se encontra Francisco se torna um verdadeiro martírio para Luciano, que se questiona: "Que iria ver? Que se daria?" (RIO, 2002, p. 154).

Porém, o visual horrendo, a monstruosidade e a deformação pela doença são visíveis:

Eu tinha diante de mim um monstro. As faces inchadas, vermelhas e em pus, os lábios lívidos, como para arrebentar em sânie. Os olhos 
desaparecidos meio afundados em lama amarela, já sem pestanas e com as sobrancelhas comidas, as orelhas enormes. Era como se aquela face fosse queimada por dentro e estalasse em empolas e em apostemas a epiderme. (RIO, 2002, p. 155)

A própria etimologia da palavra monstro, em latim monstrare, denota algo visível, que aparece, ou ainda, aquilo que serve para demonstrar e advertir (PUNTER; BYRON, 2004, p. 263). Nesse sentido, o aspecto monstruoso do rapaz denota a moléstia visível, o vírus se revelando e advertindo as pessoas para o perigo real da doença.

As feridas aparentes expõem algo que não se pode compreender e nem aceitar, pois "Uma ferida com sangue e pus, ou o cheiro doentio e acre de suor, de decadência, não significa morte. Na presença da morte significada [...] eu poderia compreender, reagir ou aceitar" (KRISTEVA, 1982, p. 3). E é por isso que o narrador fica perplexo e não consegue aceitar a aparência monstruosa do amigo.

Julia Kristeva expõe o abjeto como sendo o descartado, o excluído e o repugnante; ficando na fronteira, pois não é nem o morto e nem o vivo sadio. No caso do conto, Francisco está no limite entre o morto e o vivo ileso; terá sequelas da doença, marcas que o irão identificar como aquele que não passou por ela incólume.

O cadáver, visto sem Deus e fora de ciência, é o máximo da abjeção. É a morte infectando a vida. Abjeto. É algo rejeitado do qual não se faz parte, da qual não se protege como de um objeto. Estranheza imaginária e ameaça real, acena para nós e acaba nos engolfando. (1982, p. 4) 
Assim, podemos pensar no próprio amigo, cuja imagem é tão horrenda que só é reconhecido pela "enorme cabeleira negra" (RIO, 2002, p. 155). Transformando-se na abjeção, ele perde suas características básicas, "nada é familiar, nem mesmo a sombra de uma memória" (KRISTEVA, 1982, p. 5).

Após visitar o amigo desfigurado, o narrador acaba saindo do hospital atordoado, no momento de clímax do medo: "eu saí tropeçando, desci o morro a correr quase, entre os empregados num vaivém constante e as macas que subiam com as podridões. Um delírio tomava-me" (RIO, 2002, p. 155).

Nesse sentido, podemos pensar no efeito que o horror corporal expõe. Conforme explica Xavier Aldana Reyes, a repulsa pode ser tanto corporal quanto cultural (2020, p. 395). Em “A peste", a repulsa corporal prevalece, pois o conto nos apresenta a descrição monstruosa do amigo Francisco e a repugnância do narrador perante a cena que perpassa para os leitores.

A abjeção está ligada à repressão. Ela não monitora apenas tabus sobre o corpo, especialmente sua limpeza, mas também os padrões de comportamento humano associados a ela, que são vistos como corretos e adequados, desde comportamentos sexuais (a necessidade de se casar antes da relação sexual) até o manejo dos mortos (sepultamento) e de excrementos (saneamento). Da mesma forma, a abjeção constitui a espinha dorsal da representação cultural: o que é considerado "outro", "monstruoso" ou "nojento" é, em última análise, determinado pelo que, em qualquer ponto da história, é percebido como normativo e protegido como "normal". (REYES, 2020, p. 395, tradução nossa) 
Embora não nos ateremos à repulsa cultural, nesse conto podemos pensar também que as regras, tanto de saneamento quanto de sepultamento, estão completamente fora do normativo: ruas com cheiros podres e pessoas com seus entes falecidos nas ruas, tudo está diferente do usual.

Novamente, numa cena repulsiva, a realidade se mistura com o delírio. "Eu tinha febre. Corri mais, corri daquela casa, daquele laboratório de horror em que o africano deus selvagem da bexiga, Obaluaiê, escancarava a face deglutindo pus" (RIO, 2002, p. 156).

Obaluaiê ou Obaluaê, na cultura africana, é o orixá da cura e da morte. Tem grande poder de causar epidemias, mas também, pode curar qualquer mal, sendo o protetor dos doentes pobres.

Geralmente apresenta uma vestimenta peculiar, uma roupa de palha constituída de duas partes: a de cima, um capuz trançado na palha que passa da cintura e encobre o rosto e; a parte debaixo, uma saia, também de palha, que pode chegar até os pés. Ele também usa uma espécie de calça, nas quais carrega seus remédios.

Há duas representações para a vestimenta, uma delas seria a necessidade de deixar algo sempre oculto, daí a necessidade de cobertura. Outra é, pelo fato de o orixá ter um brilho tão intenso que mataria aqueles que se aproximam, novamente fazendo-se necessária uma proteção.

Era um guerreiro terrível que, seguido de suas tropas, percorria o céu e os quatro cantos do mundo. Ele massacrava sem piedade aqueles que se opunham à sua passagem. Seus inimigos saíam dos combates mutilados ou morriam da 
peste [...] Xapanã é considerado o deus da varíola e das doenças contagiosas. Ele tem, também, o poder de curar. As doenças contagiosas são, na realidade, punições aplicadas àqueles que o ofenderam ou conduziram-se mal. Seu verdadeiro nome, é perigoso demais pronunciar. Por prudência, é preferível chamá-lo Obaluaê, o "Rei, Senhor da Terra" ou Omulú, o "Filho do Senhor". (VERGER, 1997, p. 55-57)

É o deus das doenças contagiosas que exige respeito e submissão de seus devotos. Em "A peste", há pessoas que morreram ou saíram mutiladas, deformadas pela doença, mas é o narrador que vê a face do orixá e não escapa incólume, "E atirei-me ao bonde, tremendo, tremendo, tremendo..." (RIO, 2002, p. 156).

Logo, a peste se torna visível na vida das pessoas, e é a partir desse episódio que Luciano irá aceitar a epidemia e apresentar novamente o medo da contaminação: "Há epidemia, oh! Sim, há epidemia! E eu tenho medo, meu amigo, um grande, um desastrado pavor..." (RIO, 2002, p. 156).

A narrativa termina com uma brusca mudança de narrador, indicando um recuo no tempo e um distanciamento do fato narrado, efeito proporcionado pela inserção de uma outra voz narrativa:

E Luciano Torres, após a narrativa, caiu-me nos braços a soluçar. Era de noite e foi há dois dias. Ontem vieram dizer-me que Luciano Torres, meu amigo e colega, fora conduzido em automóvel da Assistência do seu elegante apartamento das Laranjeiras para o posto de observação. Está com varíola. (RIO, 2002, p. 156)

Estamos diante de mais um diálogo entre a obra de João do Rio com a escrita de Jean Lorrain, conforme atesta Pierini: 
Jean Lorrain abusava do discurso indireto livre [...]. Muitas vezes a narração é transferida para um terceiro personagem que reproduz diálogos com outros personagens, misturando aspas com travessões e dificultando a "devolução" da palavra ao narrador inicial, isso quando o narrador inicial não faz comentários à narração da narração do personagem no meio dela. (2019, p. 11)

A mudança súbita do narrador encaminha a história para o seu começo. O conto termina com a constatação de uma quase punição a Luciano. Inicialmente, ele que ria de toda a situação, é agora vítima de todo o seu descrédito diante das evidências proporcionadas pela epidemia que assolava a cidade. Luciano, quando soube que o amigo se retirara para o Corcovado para fugir da epidemia, o julgou como um covarde. Agora, ele, mais uma vítima do destino inexorável, testemunha e vivencia todas as nuances da doença, que na esfera do gótico lhe foi apresentada transmutada no medo e materializadas nas purulentas matizes do monstruoso.

\section{CONSIDERAÇÕES FINAIS}

"A peste" é um conto escrito num período de transição da literatura gótica, em que determinadas características passam acentuadamente por um processo de transmutação, e que serão incorporadas às novas formas de abordagem levadas adiante pelo goticismo no século XX.

Dentro do projeto literário de João do Rio, o conto, assim como os demais da obra Dentro da Noite, revela uma aproximação do jornalista e escritor com a estética do gótico, bem como uma oportunidade de abordar e problematizar temas sociais, 
no sentido de levar a pertinência dessas questões a um número maior de leitores.

Em "A peste", temos, portanto, a transfiguração do medo, que articulado com o espaço criam uma atmosfera de pavor, conduzindo meticulosamente o senso comum aos horrores de uma epidemia. Seu clímax, constituído na figura do monstruoso, antecipa os males e consequências de um estado terrível, no qual o ser humano não quer estar inserido.

Esta pode ser uma das maiores contribuições de João do Rio com a obra Dentro da Noite, e, em especial, com "A peste", pois sua escrita traz a potencialidade de convidar o leitor simpático a uma tipologia específica de literatura ao debate e discussão de temas tão complexos como a questão de saúde pública, a crença nas instituições, o discurso científico e o relacionamento humano, tudo isso a partir de procedimentos e convenções característicos da literatura gótica. O que mais nos chama a atenção é que toda essa engenhosidade se faz valer ainda hoje, mais de cem anos depois, num período de plena pandemia, não só pelos aspectos de um mal que desestabiliza uma sociedade, mas também pelas contradições e conflitos inerentes ao ser humano.

\section{REFERÊNCIAS}

ALVES, Suzana. Locus Amoenus. In: CEIA, Carlos (Coord.). E-Dicionário de Termos Literários. 2009. Disponível em: https://edtl.fcsh.unl.pt/encyclopedia/locusamoenus/. Acesso em 22 nov. 2020.

Angela Merkel: coronavírus é o maior desafio desde a II Guerra Mundial. Deutsch Welle. Berlim, 18 mar. 2020. Notícias. Internacional. Disponível em: https:// www.dw.com/pt-002/angela-merkel-coronavírus-é-o-maior-desafio-desde-aii-guerra-mundial/a-52829950. Acesso em 2 nov. 2020. 
BOTTING, Fred. Gothic. London: Routledge, 1996.

CENSO Demográfico Brasileiro. Instituto Brasileiro de Geografia e Estatística. Rio de Janeiro, 2010. Disponível em: https://censo2010.ibge.gov.br/sinopse/index. php?dados=6. Acesso em 2 nov. 2020.

FIOCRUZ. A revolta da vacina. Comunicação e informação, Notícias. Rio de Janeiro, 25 abr. 2005. Disponível em: https://portal.fiocruz.br/noticia/revoltada-vacina-2. Acesso em 2 nov. 2020.

FRANÇA, Júlio; SASSE, Pedro. O mal e a cidade: o medo urbano em "Dentro da Noite", de João do Rio. Revista e-scrita, v. 3, p. 32-45, 2012.

KRISTEVA, Julia. Powers of Horror: an Essay on Abjection. Tradução de Leon S. Roudiez. New York: Columbia University Press, 1982.

LORRAIN, Jean. Melhores contos fantásticos de Jean Lorrain. Tradução de Fábio Lucas Pierini. Londrina: EdUEL, 2019.

PUNTER, David; BYRON, Glennis. The Gothic. Oxford: Blackwell Publishing, 2004. REYES, Xavier Aldana. Abjection and Body Horror. In: Clive Bloom (Ed.). The Palgrave Handbook of Contemporary Gothic. Oxford: UK: Plagrave Macmillan, p. 393-410, 2020.

RIO, João do. Dentro da Noite. São Paulo: Antiqua, 2002.

RODRIGUES, João Carlos. João do Rio: vida, paixão e obra. Rio de Janeiro: Civilização Brasileira, 2010.

RODRIGUES, João Carlos. Prefácio. In: RIO, João do. Dentro da Noite. São Paulo: Antiqua, p. 12-13, 2012.

VERGER, Pierre Fatumbi. Lendas Africanas dos Orixás. 4. ed. Tradução de Maria Aparecida da Nóbrega. Desenhos de Carybé. Bahia: Corrupio Editora, p. 55-57, 1997. 